\title{
PERAN NILAI PERBANKAN DALAM MEMEDIASI PENGARUH NON PERFORMING LOAN DAN NET INTEREST MARGIN TERHADAP RETURN SAHAM PERBANKAN GO PUBLIC Astohar $^{1}$ dan Sinta Ratna Pratiwi ${ }^{2}$ \\ S1 Akuntansi, STIE Totalwin ${ }^{1,2}$ \\ 1) astohardemak@gmail.com \\ 2) sintaratnap1307@gmail.com
}

\begin{abstract}
ABSTRAK
Hasil penelitian terdahulu menunjukkan terjadi gap pengaruh antara non performing loan (NPL) dan net interest margin (NIM) terhadap return saham. Selain itu juga ada rekomendasi untuk membuat model penelitian factor - factor yang mempengaruhi return saham perbankan yang go public secara bertingkat (Struktural). Populasi dalam penelitian ini adalah sebanyak 43 perbankan go public. Besar sampel yang digunakan sebanyak 35 bank dengan metode pengambilan sampel menggunakan purposive sampling, sehingga jumlah observasi sebanyak 210 observasi. Alat analisis yang digunakan adalah menggunakan persamaan regresi linier berganda dan sobel test (uji mediasi). Hasil penelitian menunjukkan bahwa non performing loan (NPL) terbukti mempunyai pengaruh negative dan signifikan terhadap price book to value (PBV) dan return saham. Net interest margin (NIM) terbukti mempunyai pengaruh positif dan signifikan terhadap Price book to value (PBV) dan return saham. Price to book value mampu memediasi pengaruh net interest margin (NIM) terhadap return saham perbankan yang go public di Indonesia akan tetapi tidak mampu memediasi pada variable non performing loan (NPL).
\end{abstract}

Kata kunci : NPL, NIM, PBV dan Return Saham.

\section{PENDAHULUAN}

Bank merupakan badan usaha yang berfungsi menghimpun dana dari masyarakat dalam bentuk simpanan dan menyalurkan kepada masyarakat dalam bentuk pemberian kredit. Peranan Bank cukup penting dalam suatu perekonomia yaitu melalui jasa yang ditawarkan oleh bank untuk memudahkan masyarakat dalam bertransaksi. Bank yang sehat adalah bank yang dapat menjaga dan memelihara kepercayaan masyarakat, menjalankan fungsi yang ada, membantu kelancaran lalu lintas pembayaran serta digunakan oleh pemerintah dalam melaksanakan berbagai kebijakannya, terutama kebijakan moneter. Kesehatan bank diperlukan untuk mengembalikan kepercayaan masyarakat, mengetahui kredibilitas suatu bank, dan merupakan salah satu indikator penilaian kinerja manajemen perbankan (Fordian, 2018).

Sumber permodalan dari perbankan terdiri dari beberapa ragam sumber, satu diantaranya adalah dengan masuk pasar modal. Perbankan dalam perkembangan juga membutuhkan dana untuk berkembang, salah satu cara adalah dengan go public (Sunaryo , 2020). Pasar modal (capital market) adalah pasar untuk berbagai instrumen keuangan jangka panjang yang bisa diperjualbelikan, baik surat utang (obligasi), ekuiti (saham), reksa dana, instrumen derivatif maupun instrumen lainnya. Pasar modal merupakan sarana pendanaan bagi perusahaan maupun institusi lain (misalnya pemerintah), dan sebagai sarana bagi kegiatan berinvestasi. Dengan demikian, pasar modal memfasilitasi berbagai sarana dan prasarana kegiatan jual beli dan kegiatan terkait lainnya. Instrument keuangan (produk) yang diperdagangkan di Pasar Modal Indonesia antara lain adalah 
saham, surat utang (obligasi), reksa dana, exchange traded fund (ETF) dan derivatif (idx.co.id).

Terbentuknya pasar modal adalah adanya harga saham melalui hukum ekonomi atas permintaan dan penawaran yang terjadi. Meningkatnya harga saham pada suatu perusahaan dapat terjadi dikarenakan adanya kenaikan permintaan saham tersebut. Apabila tingkat suatu harga saham rendah dan peminantnya sedikit dapat menyebabkan meningkatnya resiko ketidaklancaran arus permodalan perusahaan karena kurangnya modal untuk menjalankan kegiatan perusahaan tersebut (Fahlevi et al, 2018 dalam Hariyani dkk, 2021). Memilih suatu investasi atau khusunya membeli saham, seorang investor harus melakukan penilaian terlebih dahulu terhadap perusahaan yang akan dituju. Salah satu cara penilaian yang dapat dilakukan dengan melihat kinerja perusahaan melalui laporan keuangan perusahaan yang di ukur menggunakan rasio keuangan (Hariyani dkk, 2021).

Pasar modal berperan penting bagi emiten yang membutuhkan tambahan dana untuk menjalankan operasional perusahaan, dan bagi investor yang memiliki kelebihan dana untuk di investasikan. Bila pasar modal efisien maka pasar modal akan memberikan return seperti yang diharapkan oleh para investor. Investor selalu menginginkan return yang tinggi namun selalu menghindari risiko. Akan tetapi, teori menyebutkan bahwa investasi yang mempunyai return tinggi pasti akan mempunyai risiko yang tinggi juga (Tandelilin, 2010 dalam Lestari dan Suaryana, 2020).

Perkembangan perbankan yang go public sampai saat ini sebanyak 43 perbankan atau memberikan pilihan bagi investor untuk membeli saham dari perbankan tersebut dengan harapan akan memberikan suatu imbalan hasil (return). Return tersebut dapat berupa pemberian dividen dan atau mendapatkan capital gain dari peningkatan harga saham yang dimiliki. Investor harus memperhatikan kinerja perusahaan perbankan untuk target keuntungan berupa deviden atau retrun saham atau capital gain. Menurut Hartono (2003) dalam Wahyuningsih dan Susetyo (2020) return saham bisa menjadi suatu indikator keberhasilan suatu perusahaan. Keinginan investor dalam berinvestasi yakni mendapkan return yang tinggi, akan tetapi saat ini, return di Indonesia memberikan hasil negatif

Banyak faktor yang mempengaruhi return saham perbankan diantaranya adalah non performing loan (NPL) atau merupakan rasio kredit bermasalah dari perbankan. Hasil penelitian Juliana (2019) menunjukkan bahwa non performing loan (NPL) mempunyai pengaruh yang negative dan signifikan terhadap return saham perbankan. Setiap peningkatan kredit bermasalah (NPL) akan berdampak pada penurunan return saham (Hariyani, dkk, 2021). Hasil berbeda ditunjukan oleh Syauta dan Widjaja (2009) bahwa NPL berpengaruh positif dan signifikan terhadap return saham. Hasil berbeda lagi ditunjukkan oleh Ayem dan Wahyuni (2017) dimana peningkatan NPL berdampak negative akan tetapi tidak signifikan terhadap return saham perbankan.

Net Interest margin (NIM) merupakan yang digunakan untuk mengetahui perbandingan antara pendapatan bunga bersih dengan rata-rata aktiva produktif yang digunakanPuntuk menghasilkan laba (Harahap \& Hairunnisah, 2017 dalam Dina dan Mandasari, 2021). Hasil penelitian dari Kuriadi (2012) menunjukkan bahwa Net Interest margin (NIM) berpengaruh positif dan signifikan terhadap return saham. Hasil penelitian ini didukung oleh Taslim dan Manda (2021) peningkatan NIM akan berdampak pada peningkatan kembalian saham (return saham). Hasil penelitian ini bertolak belakang dengan penelitian dari Laynita (2021) dimana NIM berpengaruhi positif akan tetapi tidak signifikan pada return saham. Perbedaan juga ditunjukkan oleh Yudistira dan Adiputra 
(2020) bahwa peningkatan NIM justru berdampak pada penurunan return saham perbankan yang go public.

Pada penelitian ini menambah variabel intervening yaitu price book value $(P B V)$, pemilihan variable sebagai variable interveing yang memediasi pengaruh variable non performing loan (NPL) dan net interest margin (NIM) terhadap return saham. Penelitian ini diharapkan mampu menyempurnakan hasil penelitian sebelumnya. Sehingga model penelitian yang baru adalah model structural atau bertingkat. Tujuan dari penelitian ini adalah untuk mengetahui pengaruh secara langsung antara non performing loan (NPL) dan net interest margin (NIM) secara langsung terhadap return saham perbankan go public di Indonesia ataupun yang dimediasi oleh price book to value.

\section{LANDASAN TEORI DAN PENGEMBANGAN HIPOTESIS (JIKA ADA)}

\section{Landasan Teori}

Signaling theory merupakan teori yang menggambarkan suatu tindakan yang dilakukan oleh manajemen perusahaan dalam menilai prospek perusahaan kedepannya, serta memberikan petunjuk penilaian tersebut kepada investor untuk mengambil suatu tindakan (Brigham dan Houston, 2017, dalam Patricia 2021). Perusahaan yang baik akan memberikan signal yang jelas dan sangat berguna untuk keputusan investasi, kredit dan keputusan serupa. Signaling theory akan memberi pengaruh kepada keputusan investor yang sangat mempengaruhi kondisi pasar, investor akan merespon sinyal yang masuk dengan berbagai cara, seperti mencari saham untuk dijual atau melaksanakan suatu tindakan seperti "wait and see" perkembangan yang tersedia lalu memutuskan suatu tindakan, hal ini merupakan reaksi investor untuk menghindari risiko yang lebih besar karena faktor pasar yang tidak menguntungkan (Patricia dkk, 2021).

Signaling Theory merupakan teori yang berkaitan dengan informasi yang menunjukkan adanya informasi bagi masyarakat atau calon investor mengenai manajemen perusahaan. Informasi yang lengkap, relevan, akurat, dan tepat waktu sangat diperukan oleh investor dipasar modal. Informasi ini digunakan sebagai alat analisis untuk mengambil keputusan berinvestasi. Informasi yang disajikan pada hakekatnya berupa keterangan, catatan atau gambaran baik keadaan masa lalu, saat ini maupun masa mendatang bagi keberlangsungan suatu perusahaan dan efek pasarnya (Wahyuningsih dan Susetyo, 2020).

\section{Pengembangan Hipotesis}

\section{Saham dan Return Saham}

Saham meupakan tanda bukti penyertaan kepemilikian modal/dan pada suatu perusahaan (Fahmi, 2013). Saham dipergunakan sebagai salah satu alat untuk mencari tambahan dana dengan tujuan ingin memberikan profit yang tinggi bagi pemakainya, serta memiliki dampak keputusan yang bersifat berkelanjutan (sustainable). Investor membeli saham karena mereka mengharapkan tingkat pengembalian (return) yang baik atas investasi yang mereka lakukan tanpa suatu risiko yang cukup berarti.

Return merupakan hasil yang diperoleh dari investasi. Return dapat berupa return realisasi yang sudah terjadi atau return ekspektasi yang belum terjadi tetapi yang diharapkan akan terjadi di masa mendatang (Jogiyanto, 2014). Return realisasi (realized return) merupakan return yang telah terjadi. Return realisasi dihitung berdasarkan data histori. Return realisasi penting karena digunakan sebagai salah satu pengukur kinerja 
dari perusahaan. Return histori ini juga berguna sebagai dasar penentuan return ekspektasi (expected return) dan resiko di masa mendatang.

Return ekspektasi (expected return) adalah return yang diharapkan akan diperoleh oleh investor di masa mendatang. Berbeda dengan return realisasi yang sifatnya sudah terjadi, return ekspektasi sifatnya belum terjadi. Return yang digunakan dalam penelitian ini adalah return realisasi (realized return) yang merupakan capital gain/capital loss yaitu selisih antara harga saham periode saat ini (Pt) dengan harga saham pada periode sebelumnya (Pt-1). Apabila harga saham sekarang (Pt) lebih tinggi dari harga saham periode lalu (Pt-1) maka terjadi keuntungan modal (capital gain), dan sebaliknya apabila harga saham sekarang (Pt) lebih rendah dari harga saham periode lalu (Pt-1) maka terjadi kerugian modal (capital loss)

\section{Price Book to Value}

Price to Book Value adalah rasio yang bertujuan menunjukkan perbandingan harga saham terhadap nilai buku saham (Almiyah, 2016). Keunggulan price book value yakni 1) Nilai buku mempunyai ukuran intuitif yang relatif stabil yag dapat dibandingkan dengan harga pasar, 2) Nilai buku memberikan standar akuntansi yang konsisten untuk semua perusahaan, 3) Perusahaan-perusahaan dengan earning negatif yang tidak bisa dinilai dengan menggunakan Price Earnings Ratio dapat dievaluasi menggunakan Price Book Value (Wahyuningsih dan Susetyo, 2020)

Price to Book Value atau nilai perusahaan adalah gambaran kondisi kinerja suatu perusahaan yang mempengaruhi penilaian pasar maupun investor terhadap perusahaan. Jika kinerja keuangan baik maka yield/ return yang diperoleh akan berdampak besar kepada kemakmuran pemiliknya (Nagara dan Syafitri, 2018). Menurut Nurlela dan Islahudin (2008, dalam Nuryana, 2017) menjelaskan nilai perusahaan dapat memberikan kemakmuran pemegang saham secara maksimum apabila harga saham perusahaan meningkat. Semakin tinggi harga saham, maka akan tinggi kemakmuran pemegang saham.

\section{Non Performing Loan (NPL)}

Non Performing Loan merupakan rasio yang menggambarkan tingkat kesehatan suatu bank dan juga mencerminkan kemampuan perbankan dalam mengelola kerdit bermasalah. Non Performing Loan dapat diartikan sebagai suatu pinjaman (utang) yang sulit dalam proses pelunasannya, yang biasa disebut dengan kredit macet (Yuliyanti et al, 2017). Hasil penelitian dari Maimunah dan Fahtiani (2019) menunjukkan bahwa non performing loan mempunyai pengaruh yang negative terhadap price book to value, yaitu adanya peningkatan kredit bermasalah dapat menurunkan nilai perusahaan.

Hasil penelitian dari Juliani dkk (2019) menunjukkan bahwa non performing loan $(N P L)$ mempunyai pengaruh yang negative dan signifikan terhadap price book to value $(P B V)$. Hal ini menunjukkan bahwa terjadinya peningkatan kredit bermasalah pada perbankan dapat menurunkan nilai perusahaan (Perbankan). Kredit bermasalah dapat mengancam kelangsungan atau penurunan laba perbankan, akibatnya nilai perbankan juga mengalami penurunan (Hariyani, dkk, 2021). Berdasarkan argument diatas dapat diajukan hipotesis 1 dan hipotesis 3 sebagai berikut :

$\mathrm{H}_{1}$ : Non Performing loan (NPL) berpengaruh negative dan signifikan terhadap Price book to value $(P B V)$ pada perbankan yg go public

$\mathrm{H}_{3}$ : Non Performing loan (NPL) berpengaruh negative dan signifikan terhadap return saham pada perbankan yg go public 


\section{Net Interest Margin (NIM)}

Net Interest Margin (NIM) adalah perbandingan antara pendapatan bunga bersih terhadap rata-rata aktiva produktif. Rasio ini mengindikasi kemampuan bank menghasilkan pendapatan bunga bersih dengan penempatan aktiva produktif. Semakin besar rasio ini semakin baik kinerja bank dalam menghasilkan pendapatan bunga. Namun harus dipastikan bahwa ini bukan karena biaya intermediasi yang tinggi, asumsinya pendapatan bunga harus ditanamkan kembali untuk memperkuat modal bank (Taswan, 2010 dalam Laynita dkk 2021). Net Interest Margin (NIM) merupakan rasio yang digunakan untuk mengetahui perbandingan antara pendapatan bunga bersih dengan rata-rata aktiva produktif yang digunakan untuk menghasilkan laba (Harahap \& Hairunnisah, 2017).

Hasil penelitian dari Kurniadi (2012) menunjukkan bahwa net interest margin (NIM) berpengaruh positif dan signifikan terhadap return saham perbankan. Hal ini menunjukkan bahwa adanya peningkatan net interest margin (NIM) berdampak apda peningkatan return saham perbankan. Lebih lanjut penelitian dari Taslim dan Manda (2021) menunjukkan bahwa pendapatan bersih bunga dari perbankan berdampak pada minat investor untuk mendapatkan saham, sehingga berdampak pada return saham perbankan tersbut. Berdasarkan argument diatas dapat diajukan hipoteiss 2 dan hipotesis 4 sebagai berikut.

$\mathrm{H}_{2}$ : Net interest margin (NIM) berpengaruh positif dan signifikan terhadap Price book to value $(P B V)$ pada perbankan yg go public

$\mathrm{H}_{4}$ : Net interest margin (NIM) berpengaruh positif dan signifikan terhadap return saham pada perbankan yg go public

Hasil penelitian dari Irfan dan Kharisma (2020) yang melakukan penelitian pada perusahaan manufactur di Bursa Efek Indonesia menunjukkan bahwa price book to value mempunyai dampak positif terhadap return saham. Lebih lanjut penelitian dari Pandaya, dkk (2020) melakukan penelitian pada perusahaan yang terindek LQ 45. Hasil penelitian menunjukkan bahwa kemampuan bank dalam meningkatkan nilai perusahaan berdampak terhadap peningkatan return saham perbankan go public di Indonesia.

Berdasarkan pernyataan diatas dapat diajukan hipotesis $5\left(\mathrm{H}_{5}\right)$ sebagai berikut :

$\mathrm{H}_{5}$ : price book to value $(P B V)$ berpengaruh positif dan signifikan terhadap return saham perbankan yg go public

\section{MODEL PENELITIAN}

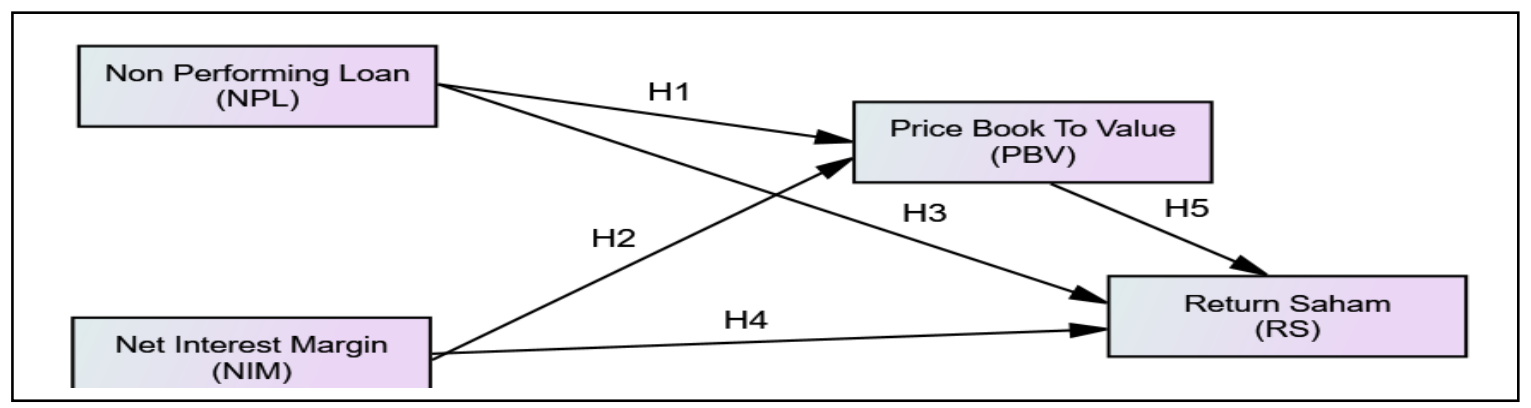

Gambar 1 Model Penelitian 


\section{METODE PENELITIAN}

\section{Definisi Konsep dan Operasional Variabel}

1) Non Performing Loan (NPL)

Non Performing Loan (NPL) adalah kecukupan modal yang menunjukkan bank dalam mempertahankan modal yang mencukupi dan kemampuan manajemen bank dalam mengidentifikasi, mengukur, mengawasi, dan mengontrol resiko-resiko yang timbul yang dapat berpengaruh terhadap besarnya modal bank (Laynita dkk, 2021).

2) Net Interest Margin (NIM)

$$
\text { NPL }=\frac{\text { Kredit Bermasalah }}{\text { Total Kredit }} \times 100 \%
$$

Net Interest Margin (NIM) merupakan rasio yang digunakan untuk mengetahui perbandingan antara pendapatan bunga bersih denganrata-rata aktiva produktif yang digunakan untuk menghasilkan laba (Harahap \& Hairunnisah, 2017).

3) Price Book to Value

$$
\mathrm{NIM}=\frac{\text { Pendapatan Bunga Bersih }}{\text { Rata }- \text { rata Aktiva Produktif }} \times 100 \%
$$

Nilai perusahaan menggambarkan seberapa baik atau buruk manajemen mengelola kekayaannya, hal ini bisa dilihat dari pengukuran kinerja keuangan yang diperoleh. Price to Book Value adalah rasio yang bertujuan menunjukkan perbandingan harga saham terhadap nilai buku saham. Price book to value diukur dengan rumus sebagai berikut (Ardimas dan Wardoyo, 2014).

$$
\begin{gathered}
P B V=\frac{\text { Harga Saham }}{\text { Nilai buku Saham }(B V)} \\
B V=\frac{(\text { Total Aktiva }- \text { Total hutang }}{\text { Saham beredar }}
\end{gathered}
$$

4) Return saham

Return saham adalah tingkat keuntungan yang dinikmati oleh pemodal atas suatu investasi yang dilakukannya. Dalam teori pasar modal, tingkat pengembalian yang diterima oleh seorang investor dari saham yang diperdagangkan di pasar modal (saham perusahaan go public) biasa diistilahkan dengan return saham. Untuk return saham perhitungannya menggunakan Capital gain (loss) yaitu keuntungan atau kerugian yang didasarkan pada penutupan harga saham periode sekarang dengan periode sebelumnya. Rumus return saham adalah sebagai berikut (Pandaya dkk (2020)

$R t=\frac{P t-P t-1}{P t-1}$

$R t=$ Return saham pad aperiode ke- $t$

$P t=$ harga saham periode pengamatan

\section{Populasi dan Sampel}

Pt-1 = harga saham periode pengamatan sebelumnya

Populasi dala penelitian ini adalah sebanyak 43 perbankan yang tercatat sampai dengan tahun 2019. Pemilihan sampel dilakukan dengan menggunakan metode purposive sampling (pertimbangan tertentu) yaitu dengan pertimbangan yaitu pada tahun 2014 2019 tersedia data dengan lengkap. Pengumpulan data menggunakan panel data selama 6 tahun periode penelitian. Berdasarkan pertimbangan - pertimbangan diatas data yang digunakan sebagai sampel adalah 35 perbankan selama 6 tahun atau 210 observasi. 


\section{Jenis dan Metode Pengumpulan Data}

Data yang digunakan adalah berupa laporan keuangan publikasi tahunan yang diterbitkan oleh Bank Indonesia yang diperoleh dari WEB OJK dari periode tahun 2014 sampai tahun 2019 dan dari WEB IDX. Sumber data yang digunakan ini diperoleh melalui penelusuran dari media internet dari www.ojk.go.id dan WEB Bursa Eek Indonesia. Metode pengumpulan data yang digunakan yaitu melalui studi pustaka dari direktori perusahaan go publik dan situs resmi tiap perusahaan.idx.go.id. serta situs - situs resmi lainnya yang dijadikan sampel.

\section{Alat Analisis Data}

\section{Uji Persamaan Regresi Ganda Tahap 1}

Analisis regresi linier berganda adalah pengaruh secara linier antara dua atau lebih variabel bebas (independen) dengan satu variabel dependen, yaitu pengaruh dari non performing loan (NPL) dan net interest margin (NIM) terhadap price book to value (PBV) (Ghozali, 2018).

Persamaan regresi pada penelitian ini terdapat dua model. yaitu sebagai berikut : $Y_{1}=a+b_{1} X_{1}+b_{2} X_{2}+b_{3} X_{3}$

Dimana :

$\mathrm{Y}_{1}: \mathrm{PBV}$

$\mathrm{X}_{1}: \mathrm{NPL}$

$\mathrm{X}_{2}: \mathrm{NIM}$

\section{Uji Persamaan Regresi Ganda tahap 2}

Analisis regresi linier berganda adalah pengaruh secara linier antara dua atau lebih variabel independen dengan satu variabel dependen, yaitu pengaruh dari non performing loan (NPL) dan net interest margin (NIM) terhadap return saham (RS). Sebelum melakukan estimasi yang tidak biasa dengan analisis regresi, perlu dilakukan uji t dan uji Fit data yaitu pengujian antar variabel bebas supaya tidak terjadi multikolinieritas, heteroskedastisitas, normalitas, dan autokorelasi (Ghozali, 2018).

Persamaan regresi pada penelitian ini terdapat dua model. yaitu sebagai berikut :

$Y_{2}=a+b_{1} X_{1}+b_{2} X_{2}$

Dimana :

$\mathrm{Y}_{2}: \mathrm{RS}$

$\mathrm{X}_{1}: \mathrm{NPL}$

$\mathrm{X}_{2}: \mathrm{NIM}$

\section{Uji Persamaan Regresi Sederhana}

Analisis regresi linier sederhana adalah pengaruh secara linier antara variabel independen dengan variabel dependen, yaitu pengaruh dari price book to vale (PBV) terhadap Return saham (RS) (Astohar, 2013).

Persamaan regresi pada penelitian ini terdapat dua model. yaitu sebagai berikut:

$\mathrm{Y}_{2}=\mathrm{a}+\mathrm{b}_{5} \mathrm{Y}_{1}$

Dimana :

$\mathrm{Y}_{2}: \mathrm{RS}$

$\mathrm{Y}_{1}: \mathrm{PBV}$

\section{Uji Koefisien Determinasi}

Koefisien determinan pada penelitian ini digunakan untuk melihat berapa persen dari variasi variabel terikat dijelaskan variabel bebas. Pada penelitian ini koefisien determinasi adalah mengetahui seberapa besar variasi return saham bank go public dapat diterangkan oleh variasi dari non performing loan (NPL) dan net interest margin (NIM). Nilai determinasi yang digunakan pada penelitian ini adalah nilai $R^{2}$. Digunakannya nilai 
tersebut karena nilai $R^{2}$ pada saat mengevaluasi model regresi dapat naik atau turun apabila satu variabel independen ditambahkan ke dalam model (Ghozali, 2018).

\section{Sobel Test}

Uji Sobel ini dilakukan dengan cara menguji kekuatan pengaruh tidak langsung variabel independen $(\mathrm{X})$ kepada variabel dependen $(\mathrm{Y})$ melalui variabel intervening $(\mathrm{M})$ dalam hal ini adalah menguji pengaruh tidak langsung variabel return on equity ratio $(R O E)$ dan loan to deposit ( $L D R)$ secara tidak langsung terhadap return saham melalui price book to value. Suatu variabel disebut variabel intervening jika variabel tersebut ikut mempengaruhi hubungan antara variabel prediktor (independen) dan variabel criterion (dependen) (Baron dan Kenny (1986) dalam Ghozali (2009). Pengujian hipotesis mediasi dapat dilakukan dengan prosedur yang dikembangkan oleh Sobel (1982) dan dikenal dengan Uji Sobel (Sobel Test).

Berdasarkan hasil perhitungan diperoleh hasil sebagai berikut :

Kriteria pengambilan keputusan :

Apabila $t$ sobel $>\mathrm{t}$ tabel : variabel terbukti sebagai variabel intervening

Apabila $\mathrm{t}$ sobel $<\mathrm{t}$ tabel : variabel tidak terbukti sebagai variabel intervening

\section{HASIL DAN PEMBAHASAN}

\section{Analisis Deskriptif}

Pada data 210 observasi tidak terdistribusi secara normal, setelah mengeluarkan 21 observasi melalui tahapan screening data menjadi normal. Data yang diolah adalah 189 observasi.

\section{Tabel 1. Deskriptif Variabel}

Descriptive Statistics

\begin{tabular}{lccccc}
\hline & N & Minimum & Maximum & Mean & Std. Deviation \\
\hline NPL & 189 & 0,00 & 15,82 & 3,1897 & 2,25124 \\
NIM & 189 & 0,39 & 11,98 & 5,0635 & 1,97316 \\
PBV & 189 & 0,00 & 4,27 & 1,4261 & 0,83058 \\
RS & 189 & $-0,56$ & 0,87 & 0,0258 & 0,29082 \\
Valid N (listwise) & 189 & & & & \\
\hline
\end{tabular}

Sumber : Data sekunder yang diolah, 2021

Pada variable non performing loan (NPL) rata-ratanya adalah sebesar 3,19 yaitu masuk dalam kategori $N P L$ yang sehat $(<5)$. Pada variable net interest margin (NIM) rata-ratanya adalah sebesar 5,06 yaitu masuk dalam kategori NIM yang adalah kurang baik (<10). Pada variabel Price book to value $(P B V)$ ini menunjukkan bahwa berdasarkan rata - rata Bank Go Public masuk dalam kategori yang kurang bagus, hal ini ditandai dengan rata - rata price book to value masih dikisaran 1,43\%. Pada variable return saham bank go public yang rata-ratanya adalah sebesar 0,026. Berdasarkan rata - rata, Bank Go Public masuk dalam kategori saham mempunyai tingkat kembalian yang kurang baik. Hal ini ditandai dengan rata - rata return saham Bank Go Public masih dibawah 1.

\section{Uji Normalitas dan Penyimpangan Asumsi Klasik}

Pada awalnya data penelitian sebanyak 210 observasi tidak terdistribusi secara normal. Setelah mengeluarkan 21 data (tersisa 189 observasi) dengan mengikuti rekomendasi dari program SPSS data yang digunakan untuk penelitian terdistribusi secara normal. Hal ini ditandai dengan print out grafik terlihat titik-titiknya nampak menyebar mendekat atau berada disekitar pada garis diagonal, serta penyebaran titik - titiknya mengikuti garis diagonal. Selain pada grafik histogram yang menunjukkan data tersebar 
mendekati garis normalitas. Berdasarkan uji Kolmogorov Smirnov sebesar 0,136 yang mana nilai signifikansi tersebut lebih besar dari nilai signifikansi yang telah ditentukan yaitu 0,05 . Berdasarkan data tersebut dapat dijelaskan bahwa model regresi telah terdistribusi secara normal.

Hasil pengujian penyimpangan asumsi klasik menunjukkan bahwa model tidak terjadi penyimpangan multikolinearitas yang ditandai dengan nilai VIF dibawah 10 yaitu : 1,$068 ; 1,080$ dan 1,076 serta nilai tolerance diatas 0,1 yaitu 0,$7937 ; 0,926$ dan 929 . Grafik scatterplot tidak membentuk pola yang khusus atau jelas, hal ini menunjukkan data tidak terjadi penyimpangan heteroskedastisitas. Nilai durbin Watson sebesar 2,014 yang mana nilai tersebut berada pada daerah tidak tidak terjadi autokorelasi.

\section{Uji Goodnes of Fit}

Hasil perhitungan anova didapatkan nilai $F$ hitungnya sebesar 7,502 nilai probabilitas adalah 0,000 . Hasil ini dikatakan bahwa permodelan yaitu variabel bebas yang berupa NPL, NIM dan PBV secara bersama - sama (simultan) mempunyai pengaruh signifikan terhadap return saham pada Bank yang Go Public, atau model yang dibangun memenuhi kriteria fit. Hal ini dapat diberikan penjelasan bahwa model yang dibangun memenuhi kriteria goodness of fit.

\section{Analisis Regresi Linier Berganda Tahap 1}

\section{Tabel 2. Persamaan Regresi Tahap 1}

\begin{tabular}{|c|c|c|c|c|c|c|}
\hline \multirow{3}{*}{ Model } & \multicolumn{3}{|c|}{ Coefficients $^{\mathrm{a}}$} & \multirow{3}{*}{$\begin{array}{c}\text { Standardized } \\
\text { Coefficients } \\
\text { Beta } \\
\end{array}$} & \multirow{3}{*}{$\mathbf{t}$} & \multirow{3}{*}{ Sig. } \\
\hline & & Unstandardize & Coefficients & & & \\
\hline & & B & Std. Error & & & \\
\hline \multirow{3}{*}{1} & (Constant) & 1,208 & 0,199 & & 6,076 & 0,000 \\
\hline & NPL & $-0,057$ & 0,027 & $-0,154$ & $-2,139$ & 0,034 \\
\hline & NIM & 0,079 & 0,030 & 0,187 & 2,598 & 0,010 \\
\hline
\end{tabular}

a. Dependent Variable: PBV

Sumber : Data sekunder yang diolah, 2021

$$
\text { PBV }=1,208-0,057 \mathrm{NPL}+0,079 \mathrm{NIM}
$$

Nilai konstanta pada penelitian ini diperoleh nilai 1,208 yang dapat diartikan bahwa tanpa adanya perubahan dari variabel bebas atau variabel non performing loan (NPL) dan net interest margin (NIM) maka nilai perusahaan (price book to value) pada Bank Go Public mengalami peningkatan

Non performing loan (NPL) Bank Go Public di Indonesia mempunyai pengaruh negatif terhadap nilai perusahaan (price book to value) dengan koefisien regresi sebesar - 0,057. Hal ini dapat diartikan bahwa setiap peningkatan Non performing loan (NPL) maka nilai perusahaan (price book to value) pada Bank Go Public di Indonesia mengalami penurunan. Hipotesis $2\left(\mathrm{H}_{2}\right)$ diterima, karena ditunjukkan dengan nilai probabilitas (sig) sebesar 0,034 yang mana nilai tersebut dibawah 0,05 atau nilai t hitung sebesar - 2,139 yang mana kurang dari - $\mathrm{t}$ tabel $(-1,96)$.

Hasil penelitian ini sejalan dengan penelitian dari Maimunah dan Fahtiani (2019) bahwa Non performing loan (NPL) mempunyai pengaruh yang negatif dan signifikan terhadap nilai perbankan yang go public di Indonesia. Hal ini menunjukkan bahwa semakin tinggi rasio kredit bermasalah akan berdampak pada penurunan nilai perbankan. Hal ini disebabkan dengan tingginya kredit bermasalah membuat investor atau masyarakat mempunyai persespsi negatif dan hal ini berdampak pada nilai perbankan yang go publik di Bursa Efek Indonesia.

Net interest margin (NIM) Bank Go Public di Indonesia mempunyai pengaruh positif terhadap nilai perusahaan (price book to value) dengan koefisien regresi sebesar 
0,079. Hal ini dapat diartikan bahwa setiap peningkatan net interest margin (NIM) maka nilai perbankan (price book to value) pada Bank Go Public di Indonesia mengalami peningkatan pula. Hipotesis $2\left(\mathrm{H}_{2}\right)$ diterima, karena ditunjukkan dengan nilai probabilitas (sig) sebesar 0,010 yang mana nilai tersebut dibawah 0,05 atau nilai thitung sebesar 2,598 yang mana lebih dari t tabel $(1,96)$.

Hasil penelitian ini sejalan dengan penelitian dari Harahap dan Hairunnisah (2017) bahwa net interest margin (NIM) mempunyai pengaruh yang positif dan signifikan terhadap nilai perbankan yang go public di Indonesia. Hal ini menunjukkan bahwa semakin tinggi pendapatan bersih dari bunga akan berdampak pada meningkatnya nilai perusahaan. Stigma di masyarakat perbankan pendapatan utamanya adalah dari pendapatan bunga, sehingga perbankan yang mampu meningkatkan pendapatan bersih bunga akan berdampak pada nilai dari perusahaan atau perbankan yang go public tersebut. Analisis Regresi Linier Berganda Tahap 2

Tabel 3. Persamaan Regresi Tahap kedua

\begin{tabular}{|c|c|c|c|c|c|c|}
\hline \multicolumn{7}{|c|}{ Coefficients $^{\mathbf{a}}$} \\
\hline \multirow[t]{2}{*}{ Model } & & Unstandardize & Coefficients & Standardized & $\mathbf{t}$ & Sig. \\
\hline & & B & Std. Error & Beta & & \\
\hline \multirow{3}{*}{1} & (Constant) & $-0,031$ & 0,070 & & $-0,446$ & 0,656 \\
\hline & NPL & $-0,021$ & 0,009 & $-0,162$ & $-2,242$ & 0,026 \\
\hline & NIM & 0,024 & 0,011 & 0,166 & 2,292 & 0,023 \\
\hline a. Deper & dent Variab & & & & & \\
\hline
\end{tabular}

Sumber : Data sekunder yang diolah, 2021

$$
\mathrm{RS}=-0,031-0,021 \mathrm{NPL}+0,024 \mathrm{NIM}
$$

Nilai konstanta pada penelitian ini diperoleh nilai - 0,031 yang dapat diartikan bahwa tanpa adanya perubahan dari variabel bebas atau variabel non performing loan (NPL) dan net interest margin (NIM) maka return saham pada Bank yang Go Public mengalami penurunan, hal ini ditandai dengan nilai konstantanya yang negatif.

Non performing loan (NPL) Bank Go Public di Indonesia mempunyai pengaruh negatif terhadap return saham pada Bank yang Go Public dengan koefisien regresi sebesar - 0,021. Hal ini dapat diartikan bahwa setiap peningkatan non performing loan (NPL) maka return saham pada Bank yang Go Public di Indonesia mengalami penurunan. Hipotesis $2\left(\mathrm{H}_{2}\right)$ diterima, karena ditunjukkan dengan nilai probabilitas (sig) sebesar 0,026 yang mana nilai tersebut dibawah 0,05 atau nilai thitung sebesar - 2,242 yang mana - t hitung kurang dari - $t$ tabel $(-1,96)$.

Hasil penelitian ini sejalan dengan penelitan yang dilakukan oleh Harahap dan Hairunisah (2017) yang mana non performing loan mempunyai pengaruh negatif signifikan terhadap return saham pada perbankan go public. Hasil penelitian ini menunjukkan dimana bank yang mempunyai tingkat kedit bermasalah yang tinggi berdampak pada penurunan permintaan saham oleh para investor dampaknya pada peningkatan kembalian saham oleh investor.

Net interest margin (NIM) Bank Go Public di Indonesia mempunyai pengaruh positif terhadap return saham pada Bank yang Go Public dengan koefisien regresi sebesar 0,024. Hal ini dapat diartikan bahwa setiap peningkatan net interest margin (NIM) maka return saham pada Bank yang Go Public di Indonesia mengalami peningkatan. Hipotesis $4\left(\mathrm{H}_{4}\right)$ diterima, karena ditunjukkan dengan nilai probabilitas (sig) sebesar 0,023 yang mana nilai tersebut dibawah 0,05 atau nilai t hitung sebesar 2,292 yang mana t hitung lebih dari t tabel $(1,96)$. 
Hasil penelitian ini sejalan dengan penelitan yang dilakukan oleh Kurniadi (2012) yang mana net interest margin (NIM) mempunyai pengaruh positif terhadap return saham pada perbankan go public. Hasil penelitian ini juga selaras dengan penelitian Taslim dan Manda (2021) dimana ada peningkatan kemampuan perbankan dalam penerimaan pendapatan bersih bunga berdampak pada permintaan saham oleh para investor, sehingga dampaknya adalah adanya peningkatan kembalian saham oleh investor.

\section{Analisis Regresi Linier Tahap 3}

Tabel 4. Persamaan Regresi Tahap 3

Coefficients $^{\mathbf{a}}$

\begin{tabular}{|c|c|c|c|c|c|c|}
\hline \multirow[t]{2}{*}{ Model } & & \multicolumn{2}{|c|}{ Unstandardized Coefficients } & \multirow{2}{*}{$\begin{array}{c}\text { Standardized } \\
\text { Coefficients } \\
\text { Beta } \\
\end{array}$} & \multirow[t]{2}{*}{$\mathbf{t}$} & \multirow[t]{2}{*}{ Sig. } \\
\hline & & B & Std. Error & & & \\
\hline \multirow{2}{*}{1} & (Constant) & $-0,109$ & 0,041 & & $-2,669$ & 0,008 \\
\hline & PBV & 0,094 & 0,025 & 0,269 & 3,821 & 0,000 \\
\hline
\end{tabular}

a. Dependent Variable: RS

Sumber : Data sekunder yang diolah, 2021

$\mathrm{RS}=-0,109+0,094$ PBV

Nilai konstanta pada penelitian ini diperoleh nilai - 0,109 yang dapat diartikan bahwa tanpa adanya perubahan dari variabel bebas atau variabel nilai perusahaan (price book to value) maka return saham pada Bank Go Public mengalami penurunan. Hal ini menunjukkan begitu pentingnya nilai perusahaan (perbankan), sehingga apabila variabel ini tetep atau tidak mengalami perubahan return saham perbankan akan mengalami penurunan.

Nilai perusahaan (price book to value) Bank Go Public di Indonesia mempunyai pengaruh positif dan signifikan terhadap return saham pada Bank yang Go Public dengan koefisien regresi sebesar 0,094. Hal ini dapat diartikan bahwa setiap peningkatan nilai perusahaan (price book to value) maka return saham pada Bank yang Go Public di Indonesia mengalami peningkatan atau sebaliknya setiap penurunan nilai perusahaan (price book to value) juga akan menurunkan return saham pada Bank yang Go Public. Hipotesis diterima pada taraf $5 \%$, karena dibuktikan dengan nilai probabilitas (sig) sebesar 0,000 yang mana nilai tersebut dibawah 0,05 atau nilai t hitung sebesar 3,821 yang mana $t$ hitung lebih dari $t$ tabel $(1,96)$.

\section{Koefisien Determinasi}

Berdasarkan hasil perhitungan diperoleh nilai koefisien determinasi ( $R$ Square) sebesar sebesar 0,101. Besar variasi variabel nilai perusahaan (price book to value) pada Bank Go Public di Indonesia yang dapat diterangkan oleh variasi variabel non performing loan (NPL) dan net interest margin (NIM) adalah sebesar 7,1\%, sedangkan sisanya sebesar 92,9 \% dipengaruhi oleh variabel lain di luar model penelitian. Besar variasi variabel return saham pada Bank yang Go Public di Indonesia yang dapat diterangkan oleh variasi variabel price book to value $(P B V)$ adalah sebesar 7,2\%, sedangkan sisanya sebesar $92,8 \%$ dipengaruhi oleh variabel lain di luar model penelitian

\section{Sobel Test}

\section{Peran price book to value (PBV) dalam Memediasi Pengaruh non performing loan} (NPL) terhadap Return saham

Berdasarkan hasil perhitungan diperoleh nilai t sobel test sebesar - 1,579 dan nilai $\mathrm{t}$ tabel sebesar 1,96. Perbandingan tersebut menunjukkan sobel - test $>-\mathrm{t}$ tabel $(-1,579$ $>$ - 1,96) sehingga dapat dijelaskan bahwa tidak ada peran price book to value $(P B V)$ dalam memediasi pengaruh non performing loan (NPL) terhadap return saham pada perbankan yang go public. Hasil tersebut menunjukkan bahwa price book to value (PBV) 
tidak terbukti signifikan dalam memediasi pengaruh non performing loan terhadap return saham pada Bank yang Go Public.

\section{Peran Price book to value (PBV) dalam Memediasi Pengaruh Net interest margin (NIM) terhadap Return saham}

Berdasarkan hasil perhitungan diperoleh nilai t sobel test sebesar 2,107 dan nilai t tabel sebesar 1,96. Perbandingan tersebut menunjukkan sobel test $>\mathrm{t}$ tabel $(2,107>1,96)$ sehingga dapat dijelaskan bahwa ada peran price book to value $(P B V)$ dalam memediasi pengaruh net interest margin (NIM) terhadap return saham pada perbankan yang go public. Hasil tersebut menunjukkan bahwa price book to value $(P B V)$ terbukti signifikan dalam memediasi pengaruh loan to deposit ratio terhadap return saham pada Bank yang Go Public.

\section{PENUTUP}

Price to book value mampu memediasi pengaruh net interest margin (NIM) terhadap return saham perbankan yang go public di Indonesia, sedangkan pada variabvel non performing loan (NPL) tidak terbukti sebagai variable mediasi. Hal ini menunjukkan peran penting dari price book to value dalam menjembati pengaruh NIM terhadap variable terikat. Secara langsung non performing loan (NPL) dan net interest margi (NIM) mampu mempengaruhi return saham perbankan yang go public.

Pihak perbankan perlu menjaga kondisi atau kinerjanya, karena investor selalu memantau kinerja perbankan. Mengoptimalkan dana yang lebih yang belum terserap oleh pinjaman dengan dimanfaatkan untuk membeli saham perbankan dari bank lainnya termasuk dimungkinkan perbankan milik sendiri agar dana yang diam bisa bergerak atau optimal. Melakukan pengembangan produk jasa keuangan seperti melakukan kemitraan pada usaha - usaha baik mikro ataupun yang menengah. Mematuhi peraturan - peraturan perbankan dan peraturan pasar modal agar tercapai pengelolaan yang baik dan dapat dipertanggungjawabkan

Untuk penelitian mendatang diharapkan model penelitian dapat dikembangkan lagi yaitu dengan menambah variabel moderating. Selain itu obyek penelitian dapat diperluas lagi pada perbankan yang terdapat unit usaha yang lebih luas (semua bank di Indonesia) serta dapat juga dengan enambah variabel yang mempengaruhi return saham pada Bank yang Go Public.

\section{DAFTAR PUSTAKA}

Ardimas, W dan Wardoyo. (2014). Pengaruh Kinerja Keuangan dan Corporate Social Responsibility terhadap Nilai Perusahaan pada Bank Go Public yang terdaftar di BEI., BENEFIT Jurnal Manajemen dan Bisnis., 18 (1). 57 - 66

Astohar. (2013). Statistika Bisnis Kasus dan Solusi. Semarang : Penerbit Duta Nusindo. Fahmi, I. (2017). Pengantar Pasal Modal. Panduan Bagi Para Akademisi Dan Praktisi Bisnis Dalam Memahami Pasar Modal Indonesia. Bandung : Alfabeta.

Fordian, D (2018). Pengaruh Kesehatan Bank Terhadap Return Saham (Studi Pada Bank BUMN yang Listing di BEI Periode 2013-2017).Fair Value : Jurnal Ilmiah Akuntansi Dan Keuangan 1 (1). 1-13

Ghozali, I. (2018). Aplikas Analisis Multivariate dengan Program IBM SPSS 25., Edisi 9. Semarang : Badan Penerbit Universitas Diponegoro.

Harahap, D. A., \& Hairunnisah, A. I. (2017). Pengaruh NPL, LDR, GCG , NIM , ROA , ROE , CAR ,BOPO terhadap Harga Saham Pada Perusahaan Perbankan Yang Terdaftar Di Bursa Efek Indonesia Dari Tahun 2010 - 2014. Jurnal Dimensi, 6 (39) $56-68$ 
Hariyani, C. Burhanudin dan Damayanti, R. (2021). Analisis Kinerja Keuangan Terhadap Harga Saham (Pada Perusahaan Perbankan Yang Terdaftar di Bursa Efek Indonesia Periode 2015-2019). Jurnal Ilmiah Bidang Ilmu Ekonomi (SOLUSI). 19 (1).

Hendayana, Y dan Nurlina. (2020). Pengaruh Economic Value Added dan Profitabilitas terhadap Return Saham pada Perusahaan Sub Sektor Perdagangan Ritel yang Terdaftar di BEI Periode 2013-2017. Kinerja Jurnal Ekonomi Dan Bisnis. 2 (2), $34-43$.

Irfan, K dan Kharisma F. (2020). Pengaruh Price to Book Value terhadap Harga Saham pada Perusahaan Manufaktur yang Terdaftar di BEI. Borneo Student Research. 1 (2) $1104-1110$

Jaya, K.A. (2015)., Pengaruh Loan To Deposite Ratio, Return On Assets, Capital Adequacy Ratio, Exchange Rate dan Interest Rate terhadap Return Saham, Jurnal Akuntansi/ XIX (3), 340-356

Jogiyanto. (2014). Teori Portofolio dan Analisis Investasi (10th ed.). BPFE. Yogyakarta.

Juliana, S.F. Pahlevi, C dan Amar, Y. (2019). Faktor-Faktor yang Mempengaruhi Return Saham perusahaan Perbankan yang Terdaftar di BEI Periode 2012-2017. JBMI. 15 (3), $305-321$.

Nagara, P dan Syafitri, M. (2018). Pengaruh ROA, ROE, BOPO, NIM dan Corporate Social Responsibility (CSR) terhadap Nilai Perusahaan pada Perbankan yang terdaftar di Bursa Efek Indonesia Periode 2011-2015., Jurnal Indovisi, 1 (1), 1 17.

Laynita, S. Hilda, M. Elfiswandi. Zefriyenni dan Lusiana. (2021) Kinerja Perusahaan Dan Bi Rate Terhadap Return Saham Bank BUMN. Jurnal Ekonomi Manajemen Sistem Informasi. 2 (4), 544 - 555.

Lestari, K, Andini R dan Oemar, A, (2016). Analisis Likuiditas, Leverage, Profitabilitas, Aktivitas, Ukuran Perusahaan dan Penilaian Pasar terhadap Return Saham (Pada Perusahaan Real Estate dan Property di BEI) Periode Tahun 2009-2014, Journal Of Accounting, 2 (2).

Lestari, MDGP dan Suaryana, IGNA, (2020). Pengaruh Nilai Tukar terhadap Return Saham dengan Profitabilitas sebagai Variabel Intervening. E Journal Akuntansi. 30 (5) $1283-1296$

Maimunah, S dan Fatiani, T (2019). Pengaruh NPL, ROA dan CAR terhadap PBV pada Perbankan BUMN, Jurnal Infromasi Perpajakan, AKuntansi dan Keuangan Publik. 14 (1). 19 -36

Nuryana,Ida, 2017., Pengaruh Tingkat Kesehatan Bank Terhadap Nilai Perusahaan Dengan Pofitabilitas Sebagai Variabel Intervening (Pada Bank Umum Swasta Nasional Periode 2011-2015., Seminar Nasional \& Call For Paper, FEB Unikama "Peningkatan Ketahanan Ekonomi Nasional Dalam Rangka Menghadapi Persaingan Global'Malang, 17 Mei, 613 - 631

Pandaya, J. Pujihastuti D dan Suprapta, I. (2020). Pengaruh Faktor Fundamental Terhadap Return Saham, Jurnal Akuntansi. 9 (2), 233 - 243.

Patricia, O. Hidayati, S. Wahyudi. (2021). Pengaruh Tingkat Kesehatan Bank terhadap Return Saham Perbankan di Indonesia. Konferensi Riset Nasional Ekonomi, Manajemen, dan Akuntansi (KORELASI). 2, 464 - 476. 
Sambul, S.H. Murni, S. Tumiwa, J. R. (2016). Pengaruh Kinerja Keuangan Perbankan terhadap Harga Saham yang Ditawarkan di Bursa Efek Indonesia (Studi Kasus 10 Bank dengan Aset Terbesar). Jurnal Berkala Ilmiah Efisiensi. 16 (02), 407 - 416.

Sunardi, H. (2010). Pengaruh Penilaian Kinerja dengan ROI dan EVA terhadap Return Saham pada perushaan yang Tergabung dalam LQ 45 di Bursa Efek Indonesia. Jurnal Akuntansi, 2 (1), 70-92.

Sunaryo, D. (2020). Pengaruh Rasio Likuiditas, Aktivitas dan Profitabilitas terhadap Return Saham Sub Sektor Perbankkan BUMN di Bursa Efek Indonesia (BEI) Periode 2010-2018. Jurnal Manajemen Bisnis (JMB). 33 (2), 25-38.

Wahyuningsih, T dan Susetyo, A. (2020). Pengaruh ROE, TVA, dan DER Terhadap Return Saham pada Perusahaan Sub Sektor Perbankan dengan PBV sebagai Variabel Intervening., Jurnal Ilmiah Mahasiswa Manajemen, Bisnis dan Akuntansi. 2 (2), 228 - 239.

Virolita, N, dan Yuliana, I. (2020). Pengaruh ROE terhadap Nilai Perusahaan dengan Struktur Modal Sebagai Variabel Moderating (Sub Sektor Makanan Minuman Tahun 2016-2018), Jurnal Ekonomi : Journal of Economic. 11 (1)., 82 - 87

Yudistira, E. R. dan Adiputra, I.M.P. (2020). Pengaruh Faktor Internal dan Ekternal Terhadap Harga Saham Jurnal Ilmiah Akuntansi dan Humanika. 10 (2), 176 - 184

Yuliyanti, L., Muntasofi, B., \& Asih, Nuraeni, D. (2017). Pengaruh Kinerja Keuangan Terhadap Harga Saham Bank Umum Konvensional di Bursa Efek Indonesia Pada Tahun 2013-2016. Jurnal Pendidikan Akuntansi Dan Keuangan, 5. 